\title{
EUROPEAN REQUIREMENTS REGARDING THE AUDIT REPORTING
}

\author{
Daniel Botez \\ Vasile Alecsandri University of Bacău \\ daniel63331@yahoo.com
}

\begin{abstract}
In recent years, reporting requirements on the statutory audit have been revised and amended to increase the audit report's communication value. In addition to the stipulations of the International Auditing Standards Package on reporting, revised and enforceable on 15 December 2016, the European Union issued the Directive 2014/56 / EU amending Directive 2006/43 / EC on statutory audits of annual financial statements and consolidated financial statements and EU Regulation no. 537/2014 on specific requirements for the statutory audit of public interest entities, both of which were published on the same date, June 17, 2014 and with the same application deadline, June 17, 2016. These normative acts foresee increased requirements for the reporting procedure in the statutory audit. Thus, the Directive provides for additional content requirements for the audit report, and the regulation requires additional information in the report but also the issuance and provision of other reports by the auditor: report to the audit committee of the public interest entity; In some cases, a report to the publicinterest entity's supervisory authority or to the auditor's supervisory authority, and a transparency report published annually on the auditor's website.

Our article details this information with direct reference to the content of these European official documents.
\end{abstract}

Keywords

European Directive regarding statutory audit; Public Interest Entities; Audit report

\section{JEL Classification}

M42

\section{Introduction}

For more than ten years, IFAC has begun a process of reviewing the International Auditing Standards (ISAs) applicable in the field of audit reporting. This process was completed in 2016 by publishing a set of revised standards and a new audit reporting standard that came into force on 15 December 2016.

At the same time, there were European concerns about amending the Statutory Audit Directive. Thus, on 17 June 2014, the Directive 2014/56 / EU amending the Directive 2006/43 / EC on statutory audits of annual financial statements and consolidated financial statements was published in the Official Journal of the European Union. On the same date, EU Regulation no. 537/2014 on specific requirements regarding the statutory audit of public interest entities. Both documents were due to be implemented and enforced in the legislation of the Member States on 17 June 2016.

A series of circumstances have caused many Member States to be unable to meet this deadline. This is also the case of Romania, who at the time of writing this article (May 2017 ) is close enough to finalizing the implementation process.

These legal acts introduce additional requirements on the reporting procedure in statutory audit, which complements and continues the series of important changes introduced by international standards. 


\section{Requirements of the Directive 2014/56 / EU and EU Regulation no. $537 / 2014$, on statutory audit report}

In art. 28 of the Directive, entitled "Preparation of the audit report", it is set out as mandatory to present the elements regarding the identification of the entity, the date and the period covered by the financial statements, the identification of the financial reporting framework, the description of the scope of the audit, mentioning the standards applied and the audit opinion. These requirements are similar to those of the International Standards on Auditing - ISAs.

In particular, the Directive requires the inclusion in the audit report of an opinion and of a statement on the annual financial statements, which refers to the auditor's obligation to issue an opinion on:

$\checkmark$ the consistency of the management's report with the financial statements for the same financial year; and

$\checkmark$ preparing the management's report in accordance with the applicable legal requirements.

Also, a statement should be included in the audit report if, based on the knowledge and understanding gained during the audit regarding the enterprise and its environment, the auditor identified significant misstatements in the management report, indicating the nature of such erroneous information.

In the auditor's report there must be a statement regarding any material uncertainty associated with events or conditions that may considerably cast doubt on the entity's ability to continue to operate.

The reader must find in the report clarifications regarding the situation in which the statutory audit was performed by several auditors (several audit firms).

Regulation no. 537/2014 on the audit of public interest entities introduces additional requirements to those laid down in the Directive applicable to this category of entities. Thus, in these reports there should be a statement about the person or the body that appointed statutory auditors or audit firms. Typically, Statutory Auditors are appointed by the General Meeting of Shareholders.

The report must also state the appointment date and the continuous mission period, including previous renewals and revalidations of statutory auditors or audit firms. It is necessary to establish compliance with the requirements on the rotation of auditors of an audit engagement to a public entity. The Regulation establishes that neither the initial assignment of a particular statutory auditor or audit firm nor any subsequent extensions may exceed a maximum of ten years, but there are some exceptions.

In support of its opinion, the auditor should disclose:

$\checkmark$ a description of the most significant disclosure risks, including the evaluated significant inaccuracy risks attributed to fraud;

$\checkmark$ a summary of the auditor's measures in response to these risks; and

$\checkmark$ where relevant, key observations on the risks involved;

Regarding the finding of irregularities, the report explains to what extent the statutory audit was considered capable of detecting them, including fraud.

Also in the auditor's report on public interest entities, the auditor confirms that the audit opinion is consistent with the additional report addressed to the audit committee.

For the purposes of the regulations specifying which services are prohibited, the auditor states that he has not provided non-audit services and that the statutory auditors or audit firms remain independent of the audited entity during the audit. Also referring to the services provided, the auditor shall indicate the possible services in addition to the statutory audit that were provided by the statutory auditor or audit firm or any member of the network of the statutory auditor or audit firm for the benefit of the audited entity ,its parent undertaking or the undertaking controlled by it and not communicated in the management report or in the statements. 
The Audit of Public Interest Entities Regulation introduces an obligation that auditors provide, in addition to the Statutory Audit Report, three other types of reports.

\section{Additional Report addressed to the Audit Committee}

In line with European requirements and Romanian legislation, public interest entities are required to have an Audit Committee. This constitutes an interface between the statutory auditor and the entity's management body.

The auditor should provide the audit committee with a report no later than the date of the statutory audit report, comprising the following:

- A declaration of independence confirming in writing, annually, to the audit committee that the statutory auditor, audit firm and partners, executives and directors conducting the statutory audit are independent of the audited entity;

- If the audit was conducted by an audit firm, the report identifies each key audit partner who was involved in the audit;

- If the Statutory Auditor or Audit Firm has taken steps to carry out its activities by another Statutory Auditor or another Audit Firm that is not a member of the same network or has made use of the work of some external experts, the report indicates this and confirms that the statutory auditor or audit firm received confirmation from the other statutory auditor or other audit firm and / or the external expert of its independence;

- A description of the nature, frequency and extent of communication with the audit committee or equivalent body of the audited entity, the management body and the administrative or supervisory body of the audited entity, including the dates of the meetings held with the bodies concerned;

- A description of the scope and timing of the audit;

- If more auditors or audit firms have been appointed, describes the distribution of attributions between statutory auditors and / or audit firms;

- Describe the methodology used, including the balance sheet items that were directly verified and whose verification was based on a systemic and conformity testing, including an explanation for any substantial variations in the differences between background and compliance testing compared with the previous exercise, even if the Statutory audit of that exercise was performed by other statutory auditors or other audit firms;

- Communicate the materiality threshold applied to the statutory audit for the overall financial statements and, where appropriate, the threshold or materiality thresholds for certain categories of transactions, balances or disclosures, and inform about the qualitative factors that were considered when determining the materiality threshold;

- Report and explain judgments about events or conditions identified during the audit that can create serious doubts about the entity's ability to continue operations, and whether these events or conditions are a substantial uncertainty and provide a summary of all warranties, letters, Public intervention commitments and other support measures taken into account in the assessment of business continuity;

- Report on any significant deficiencies in the financial statements of the audited entity or, in the case of consolidated financial statements, in the parent undertaking internal financial control system and / or in the accounting system. For each significant deficiency, the additional report shall indicate whether the deficiency in question has been or has not been resolved by the management;

- Report any significant issues involving the actual or supposed non-compliance with the laws, regulations and administrative statutes or statutes that have been identified during the audit, in so far as they are considered relevant to enable the audit committee to carry out its tasks; 
- Report and analyze the valuation methods applied to the different items in the annual or consolidated financial statements, including any impact of changing such methods;

- In the case of a statutory audit of consolidated financial statements, the auditor explains the scope of the consolidation and the exclusion criteria applied by the audited entity to non-consolidated entities, if any, and whether the criteria applied are consistent with the financial reporting framework;

- Identifies, as appropriate, any audit work performed by a third country auditor or auditors, by the statutory auditor or statutory auditors, by the entity or entities of a third country or the audit firm(s) with regard to a statutory audit of the consolidated financial statements, other than the one performed by the members of the same network to which belongs the auditor of the consolidated financial statements;

- Specifies whether the audited entity provided all explanations and documents requested;

- Reports:

$\checkmark$ Any major difficulties, if any, encountered during the audit;

$\checkmark$ Important matters, if any, that arise from the statutory audit and that have been discussed or have been the subject of correspondence with management; and

$\checkmark$ Other aspects, if any, arising from the statutory audit and which, in the auditor's professional opinion, are significant for the supervision of the financial reporting process.

\section{Report addressed to the supervisory authority of public interest entities}

\section{Report to the statutory audit's activity supervisory authority}

In certain situations specifically provided for by the Regulation, the auditor is required to prepare and report to the supervisory authority of public interest entities. Member States may require that this report be transmitted to the statutory auditing activity supervisory authority. In Romania, the supervisory authority of public interest entities is the Financial Supervisory Authority, and the statutory audit activity supervisory authority is the Public Interest Supervisory Board of the Accounting Profession. This will be transformed, according to the project of implementation of the Directive, into the Statutory Audit Activity Supervisory Authority.

The auditor of the public interest entity shall report to one of the two authorities in the following cases:

- When refusing to issue an audit opinion on the financial statements or when it intends to issue a contrary opinion or a qualified opinion. Statutory auditors or audit firms also have a duty to report any of the above-mentioned information they have become aware of during the statutory audit of an enterprise in close contact with the public interest entity in which it also carries out the statutory audit;

- When they have found a significant breach of the laws, regulations and administrative provisions which provide, as the case may be, for the conditions of authorization or which specifically regulate the conduct of activities of the public interest entity;

- When, in their view, there is a significant threat or doubt as to the continuity of the operation of that entity of interest, there is a significant threat to the continuity of the operation of that public interest entity. 


\section{Annual transparency report}

The auditor of the public interest entity has the obligation to publish a transparency report on its own website on a yearly basis. This must be published within four months of the end of the financial year and must remain on the site for at least five years.

The transparency report is updated periodically, but the original version must remain available.

This report shall include at least the following information:

- A description of the legal structure and the owners of the audit firm;

- If the statutory auditor or audit firm is part of a network:

$\checkmark$ a description of the network and its legal and structural organization;

$\checkmark$ the name of each statutory auditor operating independently or of each audit firm that is part of the network;

$\checkmark$ the countries where each independent statutory auditor or audit firm that is part of the network is authorized as statutory auditor or has its registered office, central administration or principal activity;

$\checkmark$ the total turnover achieved by the statutory auditors operating as sole practitioners and audit firms that are members of the network, resulting from the statutory audit of annual and consolidated financial statements;

- A description of the governance structure of the audit firm;

- A description of the internal quality control system of the statutory auditor or of the audit firm and a statement by the administrative or management body on the effectiveness of its functioning

- The date when the last quality assurance review was carried out;

- A list of the public interest entities for which the statutory auditor or the audit firm performed statutory audits during the preceding business year;

- A statement of practices implemented by the statutory auditor or independent audit firm, which also confirms that an internal assessment of independence has been carried out;

- A statement on the policy of statutory auditor or audit firm regarding the continuous training of the statutory auditors

- Information regarding the partners' remuneration basis in audit firms;

- A description of the statutory auditor or audit firm's policy regarding the rotation of key audit partners and staff;

- If not published in its financial statements, information about the total turnover of the statutory auditor or audit firm, broken down into the following:

$\checkmark$ income from the statutory audit of the annual and consolidated financial statements of public interest entities and entities belonging to a group whose parent undertaking is a public-interest entity;

$\checkmark$ revenues from the statutory audit of the annual and consolidated financial statements of other entities;

$\checkmark$ income from non-audited permitted services provided to entities that are audited by the statutory auditor or audit firm; and

$\checkmark$ income from non-audit services rendered to other entities.

The statutory auditor or audit firm shall provide annually to its competent authority a list of audited public interest entities, based on the revenue received from them, by dividing the respective revenues as follows:

- Statutory audit revenue;

- Income from services other than those prohibited by the Union and national law; and

- Income from services other than prohibited services not provided for by Union and national law. 


\section{Conclusion}

The additional reporting requirements of the new Statutory Audit Directive, and in particular those set out in the regulation applicable to audits of public interest entities, aim to increase the level of information for users of statutory audit reports and their confidence in financial information published.

For auditors, changes are a challenge in terms of increasing the professionalism they are showing.

\section{References}

Directive 2014/56/EU of the European Parliament and of the Council of 16 April 2014 amending Directive 2006/43/EC on statutory audits of annual accounts and consolidated accounts.

Regulation (EU) No 537/2014 of the European Parliament and of the Council of 16 April 2014 on specific requirements regarding statutory audit of public-interest entities and repealing Commission Decision 2005/909/EC. 